\title{
Demokracja chińska
}

\section{Chinese Democracy}

\author{
Jerzy Sielski ${ }^{\star}$
}

\begin{abstract}
Abstrakt
Celem opracowania jest przedstawienie pewnych czynników, które w sposób istotny wpłynęły na przyjęcie przez władze chińskie demokracji nieliberalnej. Najpierw będzie ukazany problemem związany $\mathrm{z}$ typologią systemu politycznego w dzisiejszych Chinach. Potem zostaną zaprezentowane czynniki, które rzutowały na wybór przez władze w Pekinie demokracji chińskiej (kolektywnej), a następnie podkreślone czynniki związane $\mathrm{z}$ myślą konfucjańską, które w sposób prymarny ukształtowały wizję państwa i społeczeństwa w okresie cesarstwa, a dziś zdecydowały o kształcie współczesnej demokracji nieliberalnej w Chinach. Na końcu wypada zarysować zagadnienie ,odpowiedzialności etycznej”, które dziś jest traktowane jako najistotniejsze $\mathrm{w}$ budowaniu kapitału społecznego o charakterze ogólnoświatowym.
\end{abstract}

Słowa kluczowe: autorytaryzm, demokracja kolektywna (demokracja chińska), demokracja liberalna, wzory kultury konfucjańskiej

\begin{abstract}
The main objective of this article is to present some factors which led Chinese authorities to illiberal democracy. Firstly, I will focus on the problematic issue of typology of the modern Chinese political system. Next, I will talk through factors which had an influence on choosing the so-called Chinese (collective) democracy. Subsequently, I will highlight some factors which are connected to Confucian thought. Those factors had a primary impact on forming the state and society during the era of emperors and today lead to illiberal democracy in China. In the end, I will shortly describe the question of "ethical responsibility", which is one of the key issues of creating a social capital of a global character.
\end{abstract}

Keywords: patterns of Confucian culture, authoritarianism, collective democracy (Chinese democracy), liberal democracy

\footnotetext{
* jerzysielski@op.pl; iD https://orcid.org/0000-0002-1900-6870
} 


\section{Wstęp}

Chińczycy swój system polityczny nazywają demokracją chińską albo demokracją kolektywną. Koncepcję demokracji kolektywnej stworzono na bazie negacji demokracji zachodniej. Neomarksiści uważają, że demokracja zachodnia wykorzystuje klasę robotniczą, jest więc dyktaturą burżuazji (Shih, 1999, s. 24). Podkreśla się, że prawa jednostek wynikają z faktu, iż podczas tworzenia kapitalistycznego systemu społeczno-gospodarczego na Zachodzie rolę kluczową odegrała klasa średnia, z istoty zorientowana na ochronę własnych - jednostkowych - interesów. W przypadku Chin to państwo było motorem rozwoju i przemian systemowych i to ono budowało system oparty na własności kolektywnej (Bolesta, 2006, s. 82).

Tak z reguły uzasadniają w sposób uproszczony badacze chińscy swoją demokrację nieliberalną od strony ideologicznej. Moim celem jest przedstawienie pewnych czynników, które w sposób istotny wpłynęły na przyjęcie przez władze chińskie demokracji nieliberalnej. Najpierw zastanowię się nad problemem związanym z typologią systemu politycznego w dzisiejszych Chinach. Potem zaprezentuję czynniki, które rzutowały na wybór przez władze w Pekinie demokracji chińskiej (kolektywnej). Następnie przedstawię czynniki związane z myślą konfucjańską, które w sposób prymarny ukształtowały wizję państwa i społeczeństwa w okresie cesarstwa, a dziś zdecydowały o kształcie współczesnej demokracji nieliberalnej w Chinach.

Podstawą metodologiczną pracy są cztery metody stosowane zarówno w politologii, jak i w naukach społecznych: porównawcza, czynnikowa, historyczno -politologiczna i behawioralna (Chodubski, 2004). Metoda porównawcza ma istotne znaczenie $\mathrm{w}$ rozpoznawaniu stosunków międzynarodowych. Często wykorzystuje się wymiar wzorca bądź luki. W zaprezentowanym opracowaniu ten drugi wymiar ma znaczenie. Wymiar luki polega na odkrywaniu przez podmioty polityki możliwości osiągania dla siebie różnych korzyści w przestrzeni zarówno globalnej, jak i lokalnej, np. w krajach o niższym poziomie rozwoju.

Badania porównawcze w politologii dostarczają decydentom materiału pomagającego $\mathrm{w}$ podejmowaniu decyzji optymalnych oraz $\mathrm{w}$ uniknięciu błędów popełnianych przez inne podmioty w podobnych sytuacjach.

Następne metody zastosowane w tej pracy to czynnikowa (Sielski, 2017, s. 213 i n.), historyczno-politologiczna oraz behawioralna po przez zastosowanie tych metod staram się odtworzyć zaistniałe już zjawiska polityczne (czynniki), które miały wpływ na podtrzymaniu autorytaryzmu przez władze z Pekinu. 


\section{Problem typologii systemu politycznego w Chinach}

Jak nazwać współczesny system polityczny Chin: totalitaryzm, autorytaryzm, autorytaryzm oświecony czy racjonalny (Saich, 2015), neoautorytaryzm (Zhao, 2018), oświecona dyktatura w stylu singapurskim czy też model technokratyczny oparty na silnym przywództwie partyjnym. Sami Chińczycy określają swój system mianem demokracji kolektywnej lub konfucjańskiej, bądź demokracji chińskiej (Bolesta, 2006, s. 82). Terminy te zostały stworzone na bazie negacji demokracji zachodniej utożsamionej z demokracją liberalną.

Współczesne państwo chińskie ma za podstawę cztery wzory: rodzime (przede wszystkim konfucjanizm, taoizm i legizm), radzieckie (kolektyw decyduje, komunistyczna partia jest hegemonem), zachodnie (gospodarka rynkowa), model singapurski (model technokratyczny oparty na silnym przywództwie partyjnym). Wszystkie te wzory stworzyły system społeczno-polityczny o charakterze hybrydowym.

W warstwie prawno-politycznej: ustrój polityczny Chińskiej Republiki Ludowej jest określany jako republika, państwo socjalistyczne z przewodnią rolą Komunistycznej Partii Chin (hegemon). System partyjny ChRL określono w preambule konstytucji jako „wielopartyjny system współpracy i konsultacji politycznej pod przywództwem KPCh", wraz z KPCh jest razem 9 partii (Rowiński, Jakóbiec, 2006, s. 78). W 1990 r. zrezygnowano z idei oddzielenia władzy partyjnej od państwowej. Najważniejszy organ partyjny to Biuro Polityczne Komitetu Centralnego (19-25 osób) powoływane przez KC Partii, w praktyce od początku lat 70. XX wieku wybór członków leży w gestii dotychczasowych władz.

Biuro Polityczne wybiera sekretarza generalnego (dziś Xi Jinping), który obejmuje również zwierzchnictwo nad armią, zajmując stanowisko szefa partyjnej (przewodniczący) Centralnej Komisji Wojskowej - (w Chinach armia nie podlega kontroli rządu, lecz partii komunistycznej), a także stanowisko prezydenta ChRL, jest również pierwszym członkiem Stałego Komitetu BP KPCh. W zależności od osobowości sekretarza generalnego jego władza może być silna albo też umiarkowana. Tradycja nakazuje, że duży wpływ polityczny mają też byli sekretarze generalni BP KPCh. Władza BP opiera się na tym, że jego członkowie jednocześnie zajmują wysokie pozycje $\mathrm{w}$ organach państwowych: Radzie Państwa (rząd), Ogólnochińskim Zgromadzeniu Przedstawicieli Ludowych (parlament) i w ten sposób egzekwują swoje prawa. Najściślejsza elita władzy to Stały Komitet BP KPCh. Składa się z 5-9 osób (obecnie 7). Decyzje zapadają kolektywnie.

Od 2002 roku przywódcy najwyższego szczebla mogą pełnić funkcje partyjne do 68. roku życia, a wyższego szczebla - do 65. roku życia. Wprowadzono także ograniczenie co do pełnienia funkcji przewodniczącego KPCh do dwóch 
kadencji, ale w marcu 2018 roku parlament zmienił konstytucję i usunął przepis o dwukadencyjności władz chińskich. Xi może rządzić długo...

W warstwie społecznej od roku 2000 KPCh otworzyła się na nowe grupy społeczne. Dziś obowiązuje formuła „trzech reprezentacji”. Partia reprezentuje trojakie interesy: potrzeby rozwojowe postępowych sił produkcyjnych w Chinach, „kroczenie naprzód postępowej, materialnej i duchowej kultury Chin" i „fundamentalne interesy szerokich mas narodu chińskiego" (Seitz, 2008, s. 370).

System polityczny Chin przechodził różne fazy, od systemu totalitarnego za czasów Mao, przez autorytaryzm czasów Denga, do dzisiejszej formy, która jest połączeniem neokonfucjanizmu z gospodarką rynkową. W 2001 roku ChRL wstąpiła do Światowej Organizacji Handlu (WTO). Konsekwencją przystąpienia było dostosowanie systemu prawnego do obowiązujących zasad tej organizacji. „Chiny musiały m.in. zaakceptować konieczność dobrego zarządzania (good governance). Globalizacja ekonomiczna wpłynęła na pewną liberalizację systemu politycznego oraz wzorców adaptacji do stref wolnego handlu (wciąż do kwestii spornych z partnerami z Światowej Organizacji Handlu należą ograniczenia importowe, zarówno taryfowe, jak i pozataryfowe)" (Chołaj, 2014, s. 127).

Biorac pod uwagę płaszczyznę gospodarczą, trzeba uznać gospodarka Chin to państwowa (socjalistyczna) gospodarka rynkowa. To partia i państwo nadzorują gospodarkę zarówno państwową, jak i prywatną. Kreśląc płaszczyznę polityczną, mamy do czynienia z bezwzględną dominacją Komunistycznej Partii Chin, ale celem tajże partii, jak głosi ostatni przywódca - Xi Jinping, jest dobrobyt osiagany dzięki systematycznemu rozwojowi kraju, w celu zrealizowania „chińskiego snu (marzenia)” (Liu Houbin, 2017), dlatego też jej sfera polityczna jest najbliżej - autorytaryzmu oświeconego (Bolesta, 2006, s. 81), zwanego przez Chińczyków demokracją chińską bądź demokracją kolektywną, bądź demokracją konfucjańską.

\section{Dlaczego nie demokracja?}

Po pierwsze: według Denga system autorytarny miał o wiele większe znaczenie praktyczne niż demokracja liberalna. Miała one dwa aspekty: praktyczny i ideologiczny. Przywódca Chin był synkretycznym władcą (pragmatykiem) w każdym działaniu. Utrzymał dyktaturę proletariatu (czyli partii), uzasadniając po leninowsku: że jest konieczna, aby pokonać wrogów rewolucji, według oficjalnej argumentacji. Jednak dla Denga ważniejszy był inny czynnik nie ideologiczny. Twierdził, że dyktatura jest potrzebna do utrzymania stabilności politycznej, bez której niemożliwy jest szybki wzrost gospodarczy: „,...] jeżeli 
centralny rząd coś postanowi, to postanowienie to jest szybko wcielane w życie..., kiedy na przykład zdecydowaliśmy o założeniu specjalnych stref ekonomicznych - zostały one natychmiast założone. Nie musieliśmy wdawać się w niekończące się dyskusje, w których jedna strona rządu hamuje inną, a decyzje zapadają, lecz nie są realizowane" (Excerpts..., 1992, s, 238; cyt. za: Seitz, 2008, s. 272). Ta wypowiedź to aluzja do rządów amerykańskich.

Po drugie: w dużym stopniu na pogląd o silnej i zdecydowanej władzy, a więc autorytarnej, realizował się w praktyce politycznej Singapuru, Korei Południowej, Tajwanu. Tworzyły one dynamicznie rozwijającą się silną gospodarkę dzięki silnej i zdecydowanej władzy autorytarnej. Dla Denga współcześnie politycznym wzorem przywództwa były wschodnioazjtyckie dyktatury rozwoju prezydenta Parka i Chuna w Korei Południowej, Lee Kuan Yewa w Singapurze i Chiang Kai-sheka na Tajwanie. Łączyli oni polityczną mocną samowładzę przywódcy z merkantylistyczną gospodarką rynkową (Seitz, 2008, s. 273). Podmioty te kojarzone są z dynamicznym rozwojem gospodarczym. System polityczny tych państw to „koegzystencja silnego przywódcy politycznego z nielicznym, dobrze wykształconym i dobrze opłacanym sztabem urzędników państwowych" (Pieliński, 2008, s. 211). Ten typ przywództwa określany jest mianem technokratyzmu i wykształcił się w krajach Azji Wschodniej.

Od lat 40. XX wieku w Azji Wschodniej dominują silni przywódcy polityczni. W Singapurze premierem był przez 31 lat od 1959 do 1991 roku Lee Kuan Yew, w Korei Południowej - Sygman Rhee, Park Chung Hee i Chun Doo Hwan, w Tajwanie (Chińska Republika) - Chiang Kai-shek. Współcześnie zarówno w Korei Południowej, jak i na Tajwanie model technokratyczny oparty na silnym przywódy przestał mieć rację bytu. Elity polityczne tych państw w latach 80 . XX wieku postanowiły zreformować system polityczny w kierunku demokratycznym. Dziś tylko w Singapurze możemy mówić o systemie technokratycznym i na ten model władza polityczna w Chinach spogląda jako na wzór do naśladowania $\mathrm{w}$ wielu elementach.

Po trzecie: trauma po upadku Związku Radzieckiego miała istotny wpływ na odrzucenie przez władze chińskie demokracji liberalnej (Leonard, 2009, s. 132). Dla Mao ZSRR był wzorcem, tworzył on zatem na podobieństwo Związku Radzieckiego państwo socjalistyczne. Państwo chińskie było kopią Rosji Radzieckiej. Chiny były „młodszym bratem”. A tymczasem po odsunięciu Michaiła Gorbaczowa Związek Radziecki się rozpadł, PKB ZSRR zmniejszyło się o połowę. Według władz chińskich przyczyną upadku był błąd związany z wprowadzeniem najpierw reformy politycznej, a później reformy gospodarczej. Dlatego też dziś w Chinach spotykamy się z liberalizacją ekonomiczną bez politycznej.

Po czwarte: upadek Związku Radzieckiego uwydatnił także inną bardzo groźną konsekwencję dla Chin. Do głosu w ZSRR doszły mniejszości narodo- 
we i spowodowały odłączenie się republik od macierzy. Pozostała tylko Rosja. Dlatego też wielu Chińczyków, podobnie jak i władza w Pekinie, boi się demokracji, która by spowodowała, że niektóre mniejszości narodowe i etniczne przede wszystkim Ujgurzy z Xinjian czy Tybetańczycy, głosowaliby za niepodległością, chcieliby tworzenia własnych państw narodowych, czyli odłączenia się od Chin.

Po piąte: problem Tajwanu jest przez wielu Chińczyków oraz władze w Pekinie postrzegany wieloaspektowo. ChRL uważa Tajwan za swoją odłączoną prowincję, gdzie przez 50 lat panowały autokratyczne rządy antykomunistycznego Kuomintangu. Z chwilą, gdy w 1996 roku odbyły się pierwsze wybory demokratyczne prezydenckie, Chiny kontynentalne zaczęły się bać, że społeczeństwo Tajwanu w przyszłości będzie chciało zagłosować za niepodległością. Gdyby w ChRL była demokracja, to prawdopodobnie Tajwan - tak obawia się wielu Chińczyków i władza w Pekinie - ogłosiłby niepodległość. Jednak system autorytarny w Chinach mający siłę militarną nie pozwoliłby na niezależność Tajwanu. Groźba militarna wisząca nad Tajwanem jak miecz Damoklesa powstrzymuje Tajwan od ogłoszenia niepodległości - tak myślą Chińczycy.

Po szóste: Chińczycy utożsamiają rewolucję kulturalną 1966 roku z demokracją ludową. Był to okres, który doprowadził do walki klas. Strony walczące nie przestrzegały żadnych reguł, żadnych praw, ci, co przegrywali, nie potrafili uznać swojej porażki, bili się na śmierć i życie (Leonard, 2009, s. 134). Okres ten trwający ok. 10 lat był chaosem, który doprowadził Chiny do upadku gospodarczego, politycznego i kulturalnego.

Ludzie z tego pokolenia, w szczególności klasa średnia, mają bardzo złe doświadczenia $\mathrm{z}$ tego okresu. Jedna $\mathrm{z}$ osób mimo wykształcenia i liberalnych przekonań była przerażona konsekwencjami rewolucji kulturalnej. Tak wspomina ten czas: „W młodości byłem wielkim idealistą. [...] Chciałem być szlachetnym rewolucjonistą. Wyjechałem na prowincję i przez dziesięć lat pracowałem ciężko w fabryce. Wykonywałem naprawdę najcięższe prace, ryzykując nieraz życie. Ręce miałem pokryte pęcherzami. Myślałem, że chłopi są panami historii, że są szlachetni, a my powinniśmy się zreformować, by się do nich upodobnić (pochodzę z rodziny inteligenckiej). Tymczasem okazało się, że są ludźmi takimi jak wszyscy. Widziałem grupki uczniów, którzy torturowali na śmierć swoich nauczycieli, by ukarać ich za wystawianie złych ocen. Zorganizowałem w klasie grupę osób, które broniły naszych nauczycieli przed takimi atakami. Jeśli pozwoli się ludziom na większą swobodę i wyeliminuje kontrolę, to zamienią się $\mathrm{w}$ nieprzewidywalną tłuszczę. A zatem jedyna nadzieją $\mathrm{w}$ reformie odgórnej" (Leonard, 2009, s. 133-134). 


\section{Rodzime wzory kultury politycznej wpływające na autorytaryzm władzy}

Wzory kultury politycznej mającej istotny wpływ na autorytaryzm władzy są związane z konfucjańskim systemem filozoficznym. Niektórzy badacze uważają ten system za religię. W kolejności byłby to siódmy czynnik, który wpłynął na przyjęcie demokracji nieliberalnej, czyli inaczej demokracji konfucjańskiej czyli chińskiej.

Po pierwsze: hierarchiczność. Od czasów starożytnych w Chinach szanowano hierarchię. „Chińczycy wielkim szacunkiem darzyli hierarchię kosmiczną, która obejmowała też człowieka, ustanowili więc rozróżnienie między człowiekiem a innymi istotami żyjącymi. Uważali, że dana osoba zasługuje na miano człowieka tylko wtedy, kiedy podąża słuszną drogą. Mając to na uwadze, Gantuizhi wykluczył z rodu ludzkiego barbarzyńców, zwierzęta i ptaki”" (Nakamura, 2005, s. 258).

Idea li (reguły rządzące drogą życia) była najważniejszą regułą konfucjańskiego systemu myślenia. Był to system, który tworzył pewien zespół postaw moralnych do naśladowania. Etyka li nadała dużą wartość hierarchii i pozycji społecznej. Przedstawiciele klasy niższej według tego systemu powinni jednostronnie okazywać posłuszeństwo członkom klasy wyższej. Ten aspekt konfucjanizmu cieszył się dużym poparciem władców wszystkich dynastii. Moralność konfucjańska broniła pozycji i władzy politycznej. Chińczycy akceptowali to, gdyż „od czasów starożytnych społeczeństwo opierało się na pewnym porządku wynikającym z wyróżnienia poszczególnych klas" (Nakamura, 2005, s. 263).

Najważniejszym punktem odniesienia jest rodzina, zhierarchizowana i podporządkowana podstawowym relacjom: władca - poddany, ojciec - syn, starszy brat - młodszy brat, mąż - żona. „Największe znaczenie ma »cnota synowska« [...], z której wynika moralny obowiązek bezwzględnego posłuszeństwa syna wobec ojca, wynikający z miłości do niego. W wymiarze politycznym wzorzec ten określił także stosunki między władcą a ministrami oraz między władcą a poddanymi” (Rowiński, Pawłowski, 2011, s. 17).

Jednak rewolucje, które przetoczyły się przez współczesne Chiny, zniszczyły odwieczny układ klas, ale ustanowiły nowy porządek. Hajime Nakamura tak pisze na ten temat: „W rezultacie dwóch rewolucji w czasach nowożytnych tradycyjny porządek klas społecznych został całkowicie zniszczony, ustanowiono jednakże nowy prządek. Z punktu widzenia władz komunistycznych największą rolę odgrywają żelazne reguły partyjne, które wymagają od ludzi bezwzględnego podporządkowania. W tym sensie można powiedzieć, że w Chinach nadal widać szacunek dla wyższej pozycji społecznej” (Nakamura, 2005, s. 265). 
Po drugie: władza cesarska i jego dwór. Jak silna to była tradycja, pokazuje „panowanie" Mao Zedonga w okresie powstania i trwania Chińskiej Republiki Ludowej, ale także działalność innych sekretarzy generalnych KPCh, którzy byli i są postrzegani jako kontynuatorzy władzy cesarskiej.

Mao miał silne poczucie władzy. W jego zachowaniach i poglądach można odkryć „więcej tego, co chińskie czy wręcz konfucjańskie niż komunistyczne” (Seitz, 2008, s. 191). Mao rozumiał panowanie tak jak konfucjańscy cesarze, przede wszystkim jako panowanie ideologiczne - neokonfucjanizm zmienił się w maoizm (Seitz, 2008). Stwierdził on, że świadomość przekształca materialną rzeczywistość. Inaczej mówiąc, Mao chciał najpierw stworzyć człowieka socjalizmu i dopiero za jego pomocą zbudować gospodarkę socjalistyczną. Swoją wizję gospodarki wyraził poprzez realizacje „,wielkiego skoku”, który w konsekwencji doprowadził do krachu gospodarczego, wielkiego głodu i pochłonął ponad 45 milionów ofiar (Dikōtter, 2013, s. 11).

Konrad Seitz w swojej pracy o Chinach cytuje dyplomatę i znawcę tego regionu Alaina Peyrefitte, który w 1971 roku odwiedził Chiny. Dyplomata stwierdził, że był zdziwiony podobieństwem pomiędzy państwem maoistowskim a dworem cesarza Qianlonga (1735-1796), który został opisany przez Macartney’a (1793): „[...] byłem bardzo zdziwiony osobliwym podobieństwem pomiędzy państwem maoistowskim a państwem, z którym miał do czynienia Macartney. Mao zastąpił Qianlonga i otaczany był cesarskim kultem. Wszystko zależało od jego woli. W codziennej rutynie rządzenia władza była, tak jak i w dawnych czasach, scedowana na premiera, który interpretował myśli Boga na Ziemi i lawirował pomiędzy intrygami i stronnictwami, nie posiadając żadnej innej pomocy, jak tylko przyzwolenie z góry. Jak i dawniej, dbano o rytuał protokołu, wyrażającego respekt dla tradycji i poszanowania hierarchii. Jak i dawniej, trzymano się ściśle ideologii, dającej odpowiedź na każde pytanie. Myśli Mao zastąpiły myśli Konfucjusza, a czerwona książeczka Mao zajęła miejsce świętego edyktu Kangxi" (Peyrefitte, 1989, s. xx; cyt. za: Seitz, 2008, s. 191).

„Cesarz zależnie od osobowości i aktualnej sytuacji, przekazywał większe lub mniejsze uprawnienia najwyższym urzędnikom centralnego aparatu państwowego albo też, wręcz przeciwnie, sprawował rządy osobiście, polegające jedynie na swym najbliższym otoczeniu: rodzinie lub eunuchach" (Pimpaneanu, 2001, s. 270). Dziś też w zależności od osobowości przywódcy, albo on decyduje, albo partia.

$\mathrm{Z}$ jednej strony mieliśmy Mao - władcę absolutnego, z drugiej - Denga, który był „cesarzem oświeconym”, dopuszczał do głosu innych (kierownictwo kolektywne), ale to on miał głos decydujący - decydent strategiczny. Porównać można Denga do Żółtego Cesarza architekta Chin starożytnych, gdyż Denga przedstawia się dziś jako współczesnego architekta Chin.

Mao według osobistego lekarza fascynował się historią i mnóstwo czasu poświęcił na czytanie na temat przywódców i władzy w Chinach oraz na świecie. 
Mawiał: „Musimy uczyć się z doświadczeń przeszłości by służyły teraźniejszości" (Zhisui Li, 1996, s. 117-118). Jego spojrzenie na historię było spojrzeniem władcy, cenił tych, którzy jednoczyli kraj lub też reformowali go z dobrym skutkiem np. cesarza Zhou z dynastii Shang czy cesarzową Wu Zetian (627-705). Porównywał się często z pierwszym cesarzem Qin Shihuangdi (221-206 p.n.e.), który z jednej strony zjednoczył kraj, budował drogi, a z drugiej strony skazał na śmierć 260 uczonych. Mao twierdził: „Oceniając tego cesarza, nie powinno się wyolbrzymiać rzeczy błahych, a nie zauważać wielkich" (Zhisui Li, 1996, s. 118). Podobnie było z oceną dwóch przywołanych władców: cesarza Zhou i cesarzowej Wu.

Następny przywódca Xi w mediach nazywany jest „ostatnim cesarzem”. Po zniesieniu dwukadencyjności przez dzisiejszą władzę to właśnie Xi jest ostatnim sekretarzem generalnym, a społeczeństwo chińskie ,widzi” w nim silnego władcę, kojarząc go przeto $\mathrm{z}$ historycznymi cesarzami z okresu, gdy Chiny były mocarstwem światowym. On sam czerpie wzory kultury z wielu źródeł - kultury konfucjańskiej (tradycja i rodzina, szacunek dla wartości konfucjańskich zjednuje mu sympatię rodaków), starożytnej kultury filozoficznej, posługuje się metaforami, przysłowiami i przypowieściami historycznymi (lubi cytować filozofa Han Fei zmarłego w 233 roku p.n.e. „Jeśli ci, którzy strzegą prawa, są silni to silne jest państwo. Jeśli są słabi, słabe jest państwo”), wzorami kultury związanymi z okresem Mao - potrafił się ubrać na proszony bankiet w Amsterdamie w garnitur w stylu Mao, a zarazem nie stronił od współczesnej kultury, twierdzi, że kraj należy unowocześnić, a administrację oprzeć na założeniach naukowych (szerzej zob.: Ostatni cesarz, 2014). Można dziś powiedzieć, że tworzy własne wzory kultury.

Dwaj następni sekretarze generalni: Jiang Zemin - przedstawiciel trzeciej generacji i Hu Jintao - przedstawiciel czwartej generacji przywódców, byli przez jakiś czas tylko „nominalnymi przywódcami”, czyli jak ich nazywano w nauce i mediach - ,nominalnymi cesarzami”. Jiang Zemin został sekretarzem generalnym w 1989 roku, ale nad nim góruje Deng, który najpierw w 1993 roku oddał stanowisko przewodniczącego ChRL, a stanowisko dowódcy armii w 1994 roku. Wtedy dopiero Jiang dostał pełną władzę po pięciu latach „terminowania” u Denga. Podobnie drugi przywódca, który pełnię władzy otrzymał od Jianga etapami. W 2003 roku Hu został przewodniczącym ChRL, a w 2004 roku -dowódcą armii. Obaj dopiero podczas drugiej kadencji zostali pełnymi przywódcami, czyli „cesarzami rzeczywistymi”. Jednak ich osobowości były odmienne.

Jiang swoją władzę opierał się na modelu maoistowskim (Bayer, Dziak, 2016, s. 325) (m.in. postawienie na zagadnienia ideologiczne, forsowanie masowych ruchów, pływanie we wzburzonych falach Morza Karaibskiego w meksykańskim Cancun 1997 - podobnie jak Mao przepływał rzekę w Wuhanie). Lubił „publicznie śpiewać i recytować fragmenty »Orędzia gettysburskiego« 
i innych kanonicznych dla Zachodu tekstów w języku angielskim" (McGregor, 2013, s. 30).

Hu nie miał przymiotów Denga ani Mao czy też poufałości Jianga, był wcieleniem zawodowego partyjnego biurokraty. Na początku swojej kariery sekretarza generalnego tworzył wizerunek samego siebie jako „łaskawego cesarza”, którego interwencje w politykę są mądre i doniosłe, ale rzadkie (McGregor, 2013, s. 29). Hu żył w cieniu partii.

Po trzecie: kolektywizm. Zasadą konfucjańskiego ładu społecznego była zespołowość. Jednostka jest ważna nie samoistnie, ale jako część składowa społeczności. „Społeczność, zespół - rodzina, firma, państwo - są wartościami nadrzędnymi, którym jednostka winna podporządkować całkowicie swoje interesy i służyć, poświęcając w razie potrzeby (określanej nakazem zwierzchniej władzy) wszystko, z życiem włącznie. [...] Poczucie zespołowości w dalekowschodnim kręgu kulturowym jest tym głębsze, że nie ogranicza się do doczesności - zakorzenione jest w kulcie przodków, których częścią staje się po śmierci każdy z potomnych, tracąc indywidualność. Czyli - immanentną częścią zespołu jest się tam zarówno za życia, jak i po śmierci” (Gulczyński, 2004, s. 248-249).

Wzorzec kolektywny czerpie swoją długą tradycję z dwóch źródeł: chińskiej i bolszewickiej. Zespołowość, czyli kolektyw korzystał obficie zarówno z drugiej zasady konfucjańskiego ładu społecznego - zespołowości, jak i z bolszewizmu, gdzie kolektyw był wpisany w ten system. W Chinach i w Związku Radzieckim kolektyw przede wszystkim został urzeczywistniony w postaci systemu totalitarnego, gdzie indywidualności nic nie znaczyły, dopiero w kolektywie były siłą (szerzej zob.: Sielski, 2015, s. 189 i n.).

Wzorem maoistowskiego człowieka był szeregowy Lei Feng, który w swoim dzienniku „wyznał, że pragnie być: »nigdy nie rdzewiejącą śrubką w rewolucyjnej maszynie partii« oraz »bezimiennym bohaterem«, który poświęca swe życie Wielkiemu Przewodniczącemu" (Seitz, 2008, s. 192). Współcześnie wzór władzy absolutnej został zastąpiony władzą autorytarną o charakterze technokratycznym, gdzie decyzje są podejmowane przez kolektyw - Biuro Polityczne. W wywiadzie udzielonym przez Deng Xiaopinga Orianie Fallaci w 1980 roku (Fallaci, 2012, s. 401 i n.) faktyczny przywódca Chin podkreśla wielokrotnie, że decyzje polityczne dziś są podejmowane kolektywnie.

Kolektywność to także rodzinna lojalność, która rozciąga się na cały klan, przeto może liczyć dziesiątki tysięcy ludzi. „Klan rodzinny ma nad nimi władzę, a oni go popierają. Sytuacja zmienia się w różnych regionach tego kraju, ale większość obszarów Chin mieszkańcy jednej osady należą do tego samego klanu. Na 450000000 Chińczyków istnieje tylko 470 nazwisk, a wszyscy noszący to samo nazwisko uważają się do pewnego stopnia za klanowych współbraci. Ludzie zamieszkujący dany obszar należeć mogą wyłącznie do jednego klanu, a oprócz tego uznawać za klanowych współziomków 
rodziny mieszkające w odległych miastach. [...] członkowie klanu utrzymują wspólne rodowe sanktuaria, gdzie spotykają się w określone dni, oddając cześć tysiącowi tabliczek z imionami zmarłych pochodzących od wspólnego przodka. Każdy klan posiada na własność ziemię, świątynie i dobra materialne: dysponuje też funduszami, z których łoży na wykształcenie każdego obiecującego syna rodu. Śledzi losy swych żyjących w rozproszeniu członków i wydaje starannie opracowane genealogie, aktualizowane mniej więcej raz na dziesięć lat, które zawierają imiona osób uprawnionych do korzystania z klanowych przywilejów. Klan ma swoje odziedziczone po przodkach prawa, które mogą nawet zabronić wydawania państwu przestępców, należących do rodu, jeżeli pozostawał on w konflikcie z władzami” (Benedict, 1999, s. 55-56).

Po czwarte: guanxi. Z klanowością wiąże się pojęcie guanxi, czyli tzw. sieci wpływów, powszechnej w życiu każdej jednostki w Chinach (Gruszka, 2009, s. 115 i n.). Guanxi jest społeczną rodziną, którą każdy sobie organizuje. Na początku jednostka buduje sobie guanxi, a potem przechodzi do współpracy. „Wzajemność przysług” - to główny punkt tej dość skomplikowanej instytucji społecznej, która dziś stanowi podstawę dobrego biznesu w Chinach, ale także możliwości protekcji np. w kwestii awansów. „Właściciele firm nie potrafią zatem np. obdarzyć bezgranicznym zaufaniem swoich pracowników, jeśli nie są oni członkami jednej rodziny albo nie wiąże ich silne wzajemne zobowiązania. Osobista rekomendacja jest więc o wiele więcej warta niż jakakolwiek suma pieniędzy wyłożona na stół" (Gruszka, 2009, s. 118).

Guanxi budowana jest po przez wspólną przeszłość - pochodzenie z tej samej rodziny lub regionu, wspólną pracę czy edukację (Pye, 1986, s. 2016). W szczególności guanxi ma duże znaczenie dla układu frakcyjnego wewnątrz KPCh. Z reguły jest to struktura hierarchiczna, gdzie jedna ze stron ma silniejszą pozycję. Andrew Nathan (Nathan, 1973, s. 42-43) twierdził, że frakcja jest strukturą hierarchiczną opartą na guanxi, a nie na autorytecie lidera.

W dużym stopniu dzisiejsze zasady awansu w Chinach od czasu Denga oparte są na zjawisku guanxi. Głównymi „katalizatorami” karier współczesnych chińskich polityków są (Żukiewicz, 2011, s. 261-262):

- pochodzenie - kluczowe znaczenie miało zdobycie statusu „książątka”; tak określano dzieci dygnitarzy partyjnych, które ze względu na zasługi swoich rodziców miały ułatwiony awans; dziś ta frakcja jest najsilniejsza, m.in. obecny sekretarz generalny Xi (syn Xi Zhongxuna - weterana walk rewolucyjnych $\mathrm{z}$ lat 30.); druga frakcja partyjna związana jest $\mathrm{z}$ aktywnością $\mathrm{w}$ nieformalnych i formalnych grupach i stowarzyszeniach; współcześnie można ten typ frakcji można utożsamić z frakcją młodzieżową, np. Hu był przewodniczącym Ogólnochińskiej Federacji Młodzieży; niekiedy wymienia się jako znaczącą grupę - frakcję szanghajską (Smolik, 2012, s, 145 i n.); można spotkać termin gang szanghajski, który właśnie odnosi się do tej frakcji; 
najbardziej znany przedstawiciel to Jiang Zemin i jego najbliżsi współpracownicy (Zeng Qinghongik);

- kryterium przynależności to wspólnota interesów (razem robili kariery);

- kryterium geograficzne, większość członków klanu urodziła się w Szanghaju;

- wykształcenie - np. w dużym stopniu liczyła się przynależność do stowarzyszenia absolwentów Uniwersytetu Qinghua.

- praktykowanie u mistrza - mishu - oznaczało posiadanie osobistego sekretarza, który uczy się od mistrza i zarazem korzysta z jego protekcji; taką zależność można znaleźć między Deng Xiaopingiem a Zhao Ziyangiem; Zhao pracujący na prowincji został wezwany do Pekinu w 1980 roku i mógł liczyć tylko na poparcie Denga; według niektórych badaczy faktycznie to Zhao Ziyang był autorem większości reform przypisywanych obecnie Dengowi (Bayer, Dziak, 2016, s. 271); w 1987 roku Zaho został sekretarzem generalnym KC po usunięciu Hu Yaobanga za liberalizm w polityce wewnętrznej (Bayer, Dziak, 2016, s. 300).

Wzór kulturowy guanxi to przede wszystkim struktury nieformalne i często niejawne, a one w dużym stopniu są przeciwieństwem demokracji w ujęciu zachodnim. Im więcej niesformalizowanych grup, tym bardziej one popierają silną władzę o charakterze autorytarnym.

Po piąte: biurokracja państwa. Partia dziś odwołuje się także do swojej rodzimej tradycji sprawowania władzy. Następuje renesans popularności Konfucjusza i innych zasad kulturowych związanych z tradycją chińską. Daje to dzisiejszej władzy politycznej legitymizację jako partii, która w sposób naturalny kontynuuje najwspanialsze tradycje oświeconych epok w dziejach cesarstwa. Autorytarna dzisiejsza biurokracja partyjna to przecież autorytarna centralna biurokracja cesarstwa.

Chiny są przykładem rozbudowanego systemu biurokratycznego, który ma istotny wpływ na politykę i władzę polityczną. „Cesarz, spętany pisaną i niepisaną tradycją i zobowiązany do respektowania rad i petycji doradców, miał ograniczone pole swobody politycznej. Jedynie wybitne jednostki były w stanie narzucić swoją wolę podległemu aparatowi administracyjnemu. Osoba cesarza była conditio sine qua non istnienia państwa, podczas gdy rzeczywiste prerogatywy stopniowo przechodziły w ręce urzędników" (Sarek, 2011, s. 40).

Konfucjańska kultura przeniknęła Chiny i Azję Wschodnią. Zrozumienie ich zasad moralnych i działań jest związane z kulturą Konfucjusza. Wykształceni Chińczycy stanowili oddzielną i uprzywilejowaną warstwę zwaną przez Portugalczyków - mandarynami. Byli przede wszystkim administratorami. Urzędnicy, którzy zdobyli urząd w wyniku egzaminu, tworzyli chińską merytokratyczną elitę, którą można nazwać chińską gentry. W porównaniu do angielskiej gentry warstwa ta nie dziedziczyła stanowisk, lecz zdobywała w każdym pokoleniu od nowa drogą egzaminów. „Celem konfucjańskiego wy- 
chowania było ćwiczenie społeczeństwa w posłuszeństwie oraz wykształcenie członków elit na osobowości »wewnątrzsterowne«, które wykonują powierzone zadania kierownicze w sposób odpowiedzialny i dla dobra narodu. Władanie na sposób konfucjański sprowadzało się do sprawowania moralnej kontroli nad samosterującym się społeczeństwem. Decydującą warstwą społeczną dla zapewnienia owej samosterowności była niższa gentry z prowincji, na której żyło ponad osiemdziesiąt procent ludności. Wiejska, przesiąknięta konfucjanizmem, gentry plasowała się pomiędzy górą liczącą 20000 urzędników mandarynatu a dołem złożonym $z$ setek milionów chłopów. To ona tworzyła średnią klasę, na której bazowało konfucjańskie państwo. Z tego powodu socjologowie nazywają go "państwem gentry«" (Seitz, 2008, s. 57). System ten przetrwał do 1911 roku.

Współcześnie mamy biurokrację partyjną, która stara się kontrolować aparat państwowy, społeczeństwo oraz własnych członków. Lokalna elita partyjna postrzegana jest tak jak dawniej jako tyrani, władze centralne jako ci, którzy opiekują się ludem - interwencjonizm państwowy.

W czasach, gdy myśl konfucjańska opanowała Chiny, prestiż związany był z wykształceniem. To urzędnicy, którzy zdobyli stanowisko w administracji centralnej czy lokalnej, mieli prestiż, przywileje (cała rodzina), a także bogactwo. Gdy cesarstwo znikło, nastał czas chaosu, ale od powstania ChRL przez długi czas przynależność do partii (nomenklatura partyjna) dawała prestiż i bogactwo. Dziś bogactwo materialne można uzyskać legalnie bez przynależności do partii, ale nie wolno jej się narażać. Prestiż w dalszym ciągu związany jest z partią komunistyczną.

Niekiedy badacze przedstawiają KPCh jako „cesarza zbiorowego”, Stały Komitet BP zaś - do „cesarza kolektywnego”. Uważam, że szczególnie KPCh porównanie do „cesarza zbiorowego" nie jest trafne. Nigdy nie porównywano biurokracji cesarskiej do "cesarza” i zarazem biurokracji partyjnej do sekretarza generalnego. Bardziej trafne jest porównanie Stałego Komitetu BP do „cesarza kolektywnego" w okresie dwóch sekretarzy generalnych Hu i Jiang, gdyż wtedy była przewaga partii na czele z „kolektywnym kierownictwem”.

W okresie cesarstwa biurokracja była podzielona na administrację państwową i ludową (Gawlikowski, 2009). Ta ostatnia miała siłę i żywotność, przeto gwarantowała stabilność państwa, gdy ono przechodziło kryzys. Przeciętna jednostka $\mathrm{z}$ nizin społecznych miała do czynienia z państwem rzadko, przede wszystkim był to kontakt $\mathrm{z}$ administracją ludową, czyli z organami rodowymi i gminnymi, a one zarządzały ludnością. Dlatego też „James C. Hsiung twierdzi, że w Azji Wschodniej nie mogła się zrodzić idea praw człowieka, ponieważ obywatel rzadko miał tam do czynienia z państwem. Podlegał on władzą naturalnym wspólnot klanowych i lokalnych, do których przynależał, od nich też, przede wszystkim, a nie od państwa doznawał uciski" (Hsiung, 1986, s. 22; cyt. za: Gawlikowski, 2009, s. 109). 


\section{Zakończenie}

Konfucjańska kultura przeniknęła Chiny i Azję Wschodnią. Zrozumienie ich zasad moralnych i działań jest związane z kulturą Konfucjusza i jako takie stało się głównym korzeniem omawianych tu problemów. Niemniej jednakinne czynniki wpłynęły prymarnie na decyzje o utrzymaniu demokracji nieliberalnej związanej z myślą konfucjańską. Przywołane w opracowaniu okoliczności, jak: praktyczność Denga w podejmowaniu decyzji związanej z demokracją nieliberalną czy też wzory władzy autorytarnej u sąsiadów w pierwszym okresie budowy gospodarki rynkowej, spowodowały duży wzrost gospodarczy. Myślę, że te wzory władzy autorytarnej miały największy wpływ na wybór systemu autorytarnego w systemie politycznym. W dużym stopniu także trauma po upadku Związku Radzieckiego oraz trauma związana demokracją ludową (rewolucja kulturalna) tym bardziej umocniły władzę pekińską w utrzymaniu władzy autorytarnej. Na końcu zaś problem mniejszości narodowych i etnicznych miał także istotne znaczenie w odniesieniu do decyzji o autorytaryzmie swojej władzy.

Wszystkie zasygnalizowane czynniki były istotne, ale zostały one podbudowane konfucjańskimi wzorami kulturowymi, które dziś przeniknęły do wzorów kulturowych współczesnego społeczeństwa i władzy politycznej w Chinach. To widać dziś w renesansie myśli Konfucjusza, który nauczał, że należy słuchać władzy politycznej. Dlatego obecnie w sposób naturalny władza kontynuuje najwspanialsze tradycje oświeconych epok w dziejach cesarstwa. Autorytarna dzisiejsza biurokracja partyjna to przecież autorytarna centralna biurokracja cesarstwa, to partia wybiera przywódcę, a później to on staje na czele partii i państwa.

Na koniec warto przytoczyć częsty argument, jakim Chińczycy posługują się w obronie swojej wersji demokracji. Ponieważ argumentują, że demokracja liberalna kładzie nacisk na wolność zewnętrzną, demokracja nieliberalna w wersji konfucjańskiej uwypukla wolność wewnętrzną. Celem jest doskonalenie siebie przez edukację - samodoskonalenie przez rozwijanie w sobie umiejętności, jak stać się lepszym człowiekiem wspólnoty rodzinnej i społecznej. Tutaj Chińczycy mówią o „etyce odpowiedzialności” wobec swoich obowiązków w stosunku do rodziny, społeczeństwa i państwa (Xinzhong Yao, 2009, s. 279). W dzisiejszych naukach społecznych określa się to jako budowanie kapitału społecznego. „Edukacja konfucjańska ma za zadanie przenikania do wewnętrznego świata uczącego się, opierając się na przekonaniu, że doskonalenie wewnętrznych cnót jest ważniejsze od regulowania zachowania zewnętrznego" (Xinzhong Yao, 2009, s. 281-282).

„Konfucjańskie dążenie do ustanowienia etyki odpowiedzialności zbiega się w czasie ze wzrostem świadomości globalnej i stało się częścią wspólnego, międzynarodowego poszukiwania etyki uniwersalnej, która służyłaby za 
drogowskaz światowym społecznościom XXI wieku" (Xinzhong Yao, 2009, s. 280). Dziś, należy dodać bardzo ważny czynnik, który wzmacnia autorytarne podejście władzy politycznej Chin do rządzenia państwem - nowe technologie informacyjne. Dają one władzy politycznej szerokie możliwości kontroli i manipulacji. $Z$ tego też powodu pisze się dziś o tworzeniu przez władzę chińską - dyktatury cyfrowej (Strittmatter, 2020). Jednocześnie silną pozycję Chin na scenie międzynarodowej wzmacnia idea Nowego Jedwabnego Szlaku (,jeden pas i jedna droga"), która jest globalnym projektem infrastrukturalnym i inwestycyjnym, a także planem nowego porządku międzynarodowego według pomysłu chińskiej partii (Hübner, 2020, s. 333).

\section{Bibliografia}

Bayer, J., Dziak, W.J. (2016). Historia polityczna Chin 1839-2014. Konspekt analityczny. Warszawa: Instytut Studiów Politycznych PAN.

Benedict, R. (1999). Chryzantema i miecz. Wzory kultury japońskiej. Przeł. E. Klekot. Warszawa: PIW.

Bolesta, A. (2006). Chiny w okresie transformacji. Warszawa: Dialog.

Chodubski, A.J. (2004). Wstęp do badań politologicznych. Gdańsk: Wydawnictwo Uniwersytetu Gdańskiego.

Chołaj, H. (2014). Kapitalizm konfucjański. Warszawa: Poltekst.

Dikōtter, F. (2013). Wielki głód. Tragiczne skutki polityki Mao 1958-1962. Przeł. B. Gadomska. Wołowiec: Wydawnictwo Czarne.

Excerpts from Talks in Wuchan, Shenthen, Zhuhai, and Shanghai (January 18February 21, 1992) in Selected Works of Deng Xiaoping, Vol. 3. Pobrano z: Excerpts from Talks in Wuchan, Shenthen, Zhuhai, and Shanghai (January 18-February 21, 1992) in Selected Works of Deng Xiaoping (data dostępu: 12.05.2021).

Fallaci, O. (2012). Wywiad z władza. Przeł. H. Borkowska. Warszawa: Świat Książki.

Gawlikowski, K. (2009). Konfucjański model państwa w Chinach. Warszawa: Instytut Nauk Politycznych PAN.

Gruszka, A. (2009). Fenomen guanxi w kulturze Chin. W: M. Pietrasiak, D. Mierzejewski (red.), Chiny i Japonia. Dylematy mocarstw w Azji Wschodniej. Łódź: Wydawnictwo Uniwersytetu Łódzkiego.

Gulczyński, M. (2004). Panorama systemów politycznych świata. Warszawa: Wydawnictwo Sejmowe.

Hsiung, C.J. (1986). Human Rights In an Asian Perspective. In: J.C. Hsiung (ed.), Human Rights in East Asia: A Cultural Perspective. New York: Paragon House.

Hübner, W. (2020). Procesy globalizacji a chińska Inicjatywa Pasa Drogi: perspektywa historyczna i wyzwania współczesne. W: J. Kornaś, Ł. Danel, R. Lisia- 
kiewicz (red.), Dylematy rozwoju systemów politycznych Europy i Azji. Toruń: Adam Marszałek.

Leonard, M. (2009). Zrozumieć Chiny. Przeł. W. Falkowski. Warszawa: Nadir/Media Lazar.

Liu Houbin (2009). Korzenie historyczne $i$ wktad kulturowy odrodzenia narodu chińskiego. Przeł. A. Kowalska. Toruń: Time Marszałek Group.

McGregor, R. (2013). Partia. Sekretny świat komunistycznych władców Chin. Przeł. M. Król. Kraków: Wydawnictwo Uniwersytetu Jagiellońskiego.

Nakamura, H. (2005). Systemy myślenia ludów Wschodu. Indie, Chiny, Tybet i Japonia. Kraków: Wydawnictwo Uniwersytetu Jagiellońskiego.

Ostatni cesarz (2014). Forum 24.

Nathan, J.A. (1973). A Factionalism Model for CCP Politics. The China Quarterly, 53.

Peyrefitte, A. (1989). L'empire im mobile o ule choc des mon des. Paris: Fayard.

Pieliński, B. (2008). Technokratyczne przywództwo. Władza w Azji Wschodniej. W: B. Szklarski (red.), Gra w przywództwo - jak zdobyć i utrzymać władzę. Warszawa: Collegium Civitas.

Pimpaneanu, J. (2001). Chiny. Kultura i tradycje. Przeł. I. Kałużyńska. Warszawa: Dialog.

Pye, L.W. (1986). On Chinese Pragmatism in the 1980s. The China Quarterly, 106.

Rowiński, J., Jakóbiec, W. (2006). System konstytucyjny Chińskiej Republiki Ludowej. Warszawa: Wydawnictwo Sejmowe.

Rowiński, J., Pawłowski, J. (2011). Wizja „państwa” w Chinach. Tradycja a współczesność. W: E. Zajdler (red.), Zrozumieć Chińczyków. Kulturowe kody społeczności chińskich. Warszawa: Dialog.

Saich, T. (2015). Governance and Politics of China. London: Palgrave.

Sarek, K. (2011). Z mandatu nieba. Podstawy sprawowania władzy politycznej w dawnych i współczesnych Chinach. W: E. Zajdler (red.), Zrozumieć Chińczyków. Kulturowe kody społeczności chińskich. Warszawa: Dialog.

Seitz, K. (2008). Chiny. Powrót olbrzyma. Przeł. T. Mazur. Warszawa: Dialog.

Shih, Ch. (1999). Collective Democracy: Political and Legal Reform in China. Hong Kong: Chinese University of Hong Kong Press.

Sielski, J. (2017). Czynnikowa koncepcja przywództwa na tle innych teorii. W: J. Nocoń (red.), Zagadnienia teorii polityki. Gdańsk: Instytut Politologii Uniwersytetu Gdańskiego.

Sielski, J. (2015). Polityczne wzory osobowościowe przywódców politycznych w Chinach. W: J. Marszałek-Kawa, K.J. Helnarska (red.), Polityka państw azjatyckich. Wyzwania i dylematy. Toruń: Wydawnictwo Adam Marszałek.

Smolik, B. (2012). Elita polityczna Chińskiej Republiki Ludowej w dobie dominacji czwartej generacji chińskich przywódców - przykład na przyszłość? W: W.J. Dziak, K. Gawlikowski, M. Ławacz (red.), Chiny w XXI wieku. Perspektywy rozwoju. Warszawa: Instytut Studiów Politycznych PAN.

Strittmatter, K. (2020). Chiny 5.0. Jak powstaje cyfrowa dyktatura. Przeł. A. Gadzała. Warszawa: Grupa Wydawnicza Foksal. 
Xinzhong Yao (2009). Konfucjanizm. Wprowadzenie. Przeł. J. Hunia. Kraków: Wydawnictwo Uniwersytetu Jagiellońskiego.

Zajdler, E. (red.) (2011). Zrozumieć Chińczyków. Kulturowe kody społeczności chińskich. Warszawa: Dialog.

Zhao Ch. (2018). Rational Authoritarianism and Chinese Economic Reform. In: W.P. Preston, J. Haacke (eds.), Contemporary China: The Dynamics of Change at the Start of New Millennium. New York: Routledge.

Zhisui Li (1996). Prywatne życie przewodniczacego Mao. Przeł. Z. Zaczyn. Warszawa: Philip Wilson.

Żukiewicz, P. (2011). Przywództwo polityczne. Teoria i praktyka. Warszawa: Difin. 